The University of Akron

\title{
IdeaExchange@UAkron
}

Proceedings from the Document Academy

University of Akron Press Managed

December 2014

\section{Listening to Shells and Discovering a Lost World; Epiphanic Experiences at the Museum}

Catherine M.C. Closet-Crane

Kent State University - Kent Campus, cclosetc@kent.edu

Please take a moment to share how this work helps you through this survey. Your feedback will be important as we plan further development of our repository.

Follow this and additional works at: https://ideaexchange.uakron.edu/docam

Part of the Scholarly Communication Commons

\section{Recommended Citation}

Closet-Crane, Catherine M.C. (2014) "Listening to Shells and Discovering a Lost World; Epiphanic Experiences at the Museum," Proceedings from the Document Academy: Vol. 1 : Iss. 1 , Article 9.

DOI: https://doi.org/10.35492/docam/1/1/9

Available at: https://ideaexchange.uakron.edu/docam/vol1/iss1/9

This Conference Proceeding is brought to you for free and open access by University of Akron Press Managed at IdeaExchange@UAkron, the institutional repository of The University of Akron in Akron, Ohio, USA. It has been accepted for inclusion in Proceedings from the Document Academy by an authorized administrator of

IdeaExchange@UAkron.For more information, please contact mjon@uakron.edu, uapress@uakron.edu. 


\section{Listening to Shells and Discovering a Lost World; Epiphanic Experiences at the Museum}

With the aim to explore the potential usefulness of an autoethnographic approach to the study of what happens when people encounter personally significant and memorable documents, I will narrate in this paper the lived experiences of two museum visitors (a couple) after their accidental "discovery" of a pre-Columbian engraved lightning whelk shell artifact exhibited at the Museum of the Red River in Idabel (OK). Intrigued by the provenance of this exceptional left-handed marine shell from Spiro Mounds in Oklahoma, the couple experienced an "epiphany" --defined by Ellis, Adams, and Bochner as a "self-claimed phenomena in which one person may consider an experience transformative while another may not" (Ellis et al., 2011, section 2, paragraph 2 ). As a result, they embarked on a quest for knowledge spurred by a desire to elucidate what they saw as mysterious connections between the occurrence of lightning whelk shells at Spiro Mounds, the Mississippian site of Cahokia in Illinois, and Maya sites of the Yucatán peninsula that they had visited and the empty shells and living specimens of lightning whelks they had found along the coasts of the Gulf of Mexico. During their voyage of exploration they recollected shared memories from previous travels to Yucatán and Quintana Roo, engaged in discussions with archeologists and museums' staff, collected shells, and searched through books and scholarly papers for information on lightning whelks, their provenance, archeological distribution, and ancient uses. They rejoiced in experiencing "aha moments" together and in discovering the multiple uses of the shell in preColumbian cultures of Northern America from the Atlantic Ocean in the South East to the Mississippi and Missouri rivers in the Midwest, and from the Gulf of Mexico to the Great Lakes. Following the trail of the predatory mollusk, they journeyed to Florida looking for the possible provenance of Spiro left handed shells and constructed for themselves a story of the museum object's life in preColumbian time from marine shell to document of the Spiro people.

The purpose of the story told later in this paper is to "illustrate facets of [a particular] cultural experience" (Ellis et al., 2011, section 2, paragraph 5) and contribute to the conversation about the transformative power (Carr, 2006; Woodbrook, 2012) of museum objects as documents (Briet, 1951/2008; Buckland, 1991, 1998; Latham, 2012). The story is an illustration of what I call epiphanic experiences, which are "emancipatory" (Carr, 2004, p. 5) and act as catalysts for what Carr describes as "intentional experiences that move thought forward ... transmit possibility and move the person closer to crafting the meaning of things" (2004, p. 4). By using a personal narrative my aim is to propose an evocative autoethnography that others can read and learn from to 
construct useful knowledge (Hamdan, 2012, p. 587) in research areas ranging from museum-goers' experiences to intrinsically motivated adult learning.

\section{Background}

\section{Self-Disclosure}

I sometimes feel like an outsider in the LIS field because I came to it by following a circuitous path that took me from civil engineering and urbanism to architecture, art history, and finally to library and information management. Still, I see a common thread throughout my studies and career: I have always been concerned with people and how they are impacted by what surrounds them and by the experiences in their lives. I suppose one could simply call that an interest in psychology; but, I sense that what I seek to understand cannot be labeled so easily. I want to feel and be moved by gaining knowledge, and I wish to be compelled to act and bring change.

My participation at DOCAM'14 was a transformative experience; I finally felt like I belonged with this special group of colleagues coming from different perspectives but strongly connected by their common interest in documentation and enthusiastic embrace of each other's work with/about documents. I want to call what happened in Kent an epiphany. It is this "epiphanic" experience that encouraged me to re-write my presentation into this paper.

In recent years, I became curious about autoethnography as a genre of ethnography that incorporates personal experiences; I studied it as a research method and learned about ways of doing autoethnography. In this paper I attempt an autoethnography derived from my storytelling performance and exhibit of a related painting during my presentation of "Listening to Shells and Discovering a Lost World" at DOCAM'14. By using an evocative genre of autoethnographic writing and omitting the discussion section of more conventional scholarly literature, I aim to preserve the authenticity of my original presentation to let readers -and myself- entertain the possibilities for analysis and interpretation offered by narrative-as-data.

\section{Positions on Documentation, Documents, Epistemology, Ontology, and Research Methods}

As a LIS scholar I am interested in the acts and processes associated with documenting and in people's use of and interactions with documents and information in various environments and situations. Perhaps because I was born 
and raised in France, my approach to LIS (library and information science) and LAM (library, archive, and museum) studies embraces a definition of Documentation with a capital "D" and my understanding of "what is a document" is inclusive of objects, artifacts, art, architecture, monuments, and culturally significant sites and landscapes. In the formative years of my life I was immersed in a cultural and social landscape where documentation centers and museums were familiar places in which "things" (discovery, learning, intellectual growth) happened. In that context, libraries were nearly dead institutional settings because the only specimen I knew of was the small school library where the teacher sent us from time to time to pick a book. In retrospect, I see that in my life-world (Schutz \& Luckmann, 1973) Madame Briet's views on documents and documentation ruled.

From the very beginning, Latin culture and its heritage have given to the word document the meaning of instruction and proof. RICHELET's dictionary, just as LITTRÉ's, are two French sources that bear witness to this. A contemporary bibliographer concerned about clarity has put forth this brief definition: "A document is a proof in support of a fact." (Briet, 1951/2006, p. 9)

As for the type of researcher I am, I work a little like a tinkerer. I attribute to my training in and practice of architectural design and art my inclination for studying process. As explained by a fellow architect/autoethnographer, I was "indoctrinated into the iterative cycle of reasoning-designing-evaluating" (Ericksson, 2010). I like to take things apart and observe how they fit together. Collage and bricolage, disassembling and reassembling, thinking about how I go about it are familiar processes that dominate my research interest and influence my choice of research methodologies. A "moderate social constructionist point of view of reality tempered by a critical realist approach to ontology" (Closet-Crane, 2009 , p. 61) serve as my philosophical framework and I favor qualitative research methods that incorporate working with language, texts, and documents such as ethnographic and discourse analytical approaches. In fact, I am compelled to confess that I just corrected a lapsus linguae; I had typed "discourse analyrical approaches" a portmanteau word that appropriately translates my imagining the interpretation of autoethnographic writing as lyrical analysis. 


\section{Autoethnography}

\section{How I became interested in autoethnography.}

I first became aware of autoethnography described as a genre of ethnographic participant-observation occurring in the researcher's cultural context that is sometimes called self- ethnography (Alvesson, 2003, p. 175). Reading Carolyn Ellis's The ethnographic I: A methodological novel about autoethnography (2004) was like discovering a new continent in the world of research methods. I immediately wanted to wrap my mind around autoethnography as method and get my hands on more of Ellis' published works.

Her early autoethnographies dealt with intense and traumatic experiences such as death (1993) and illness (1999) and when I discovered Ellis' s scholarship, I was struggling with my father's recently diagnosed brain cancer and the perspective of losing him too soon, and regularly cursing the shortcomings of the French medical establishment. I saw a possibility to create something out of my family's experiences with the ineptitude of information transfer practices within the medical system. I thought about studying the informational problems patients and families are faced with from diagnosis and treatment of a terminal illness through end-of-life care. I did not pursue that line of thinking further; but I began to study autoethnography as method in earnest.

In "Heartful autoethnography" (1999), parts of Ellis's descriptions of the nature of autoethnography resonated with me.

An ethnography ... includes researchers' vulnerable selves, emotions, bodies, and spirits; produces evocative stories that create the effect of reality; celebrates concrete experience and intimate detail; [and] examines how human experience is endowed with meaning .... [The] goal is to extend ethnography to include the heart, the autobiographical, and the artistic text. (p. 669)

However, I struggled with the notion that autoethnography must also include "concerns with moral, ethical, and political consequence; ... [encourage] compassion and empathy; ... [and help] us know how to live and cope" (Ellis, 1999, p. 669). I saw those concerns becoming a focus of her later explanations of autoethnographic studies (Ellis, 2004) and I wondered if Ellis envisioned autoethnography as a vehicle for catharsis exclusive of other objectives. I did not want to indulge in what critics of autoethnographies often call navel gazing (Muncey, 2010, p. XVI; Hemmingson, 2008, p. 8). After studying the writings of 
autoethnographers in various fields (Anderson, 2006; Ellis \& Bochner, 2000, 2006; Ellis et al., 2011; Hamdan, 2002; Chang, 2008, 2013), I came to realize that autoethnography is multiform and encompasses different approaches to research and genres of writings. I now understand that good autoethnography does not read as a selfish exercise in navel gazing but has the power of a lens that focuses the reader on critical analysis of human experience.

\section{Autoethnography: definitions and debates.}

Ellis et al. (2011) define autoethnography as "an approach to research and writing that seeks to describe and systematically analyze (graphy) personal experience (auto) in order to understand cultural experience (ethno)" ("History of Autoethnography" section, para. 1). Hamdan (2002) defines autoethnography as a type of qualitative research method using the "researcher's personal narrative, or autoethnography ... a a a source of privileged knowledge" (p. 585) and for him, "the reading and writing of self-narratives provides a window through which self and others can be examined and understood" (Chang, cited in Hamdan, 2002, p. 587). For Chang (2008), autoethnography as method is both researcher and reader friendly in that the researcher gains easy access to primary data and the reader easily engages with a writing style uncharacteristic of traditional scholarly writing; moreover, through the process of doing, sharing, and reading autoethnography both researchers and readers/listeners are changed. The experience is not only transformative but empowering in that action can ensue as a result of epiphanic insight.

A special issue of the Journal of Contemporary Ethnography (2006, Volume 35 ) is entirely devoted to autoethnography. In it, Anderson (2006) sheds light on the history of autoethnography; he places the origins of its development in the Second Chicago School of urban sociology with what he describes as the "biographically opportunistic research" and related ethnographies produced by ethnographers from that school (2006, p. 375). He then proposes that we must differentiate between evocative and analytic autoethnography (2006, p. 374). Finding evocative ethnography limiting, Anderson explains that evocative autoethnographers "[invoke] an epistemology of emotion, moving the reader to feel the feelings of the other" (Denzin cited in Anderson, 2006, p. 377). As Anderson sees it, evocative autoethnography focuses on "creat[ing] emotional resonance with the reader" (2006, p. 377) through compelling story telling but eschews addressing the insight gained by the researcher into broader social phenomena. It is quite obvious that Anderson's critique targets the autoethnographic approach advocated by Carolyn Ellis and Art Bochner (Ellis, 
1997, 1999, 2004; Ellis \& Bochner, 2000, 2006) and their genre of autoethnographic writing.

Anderson (2006) positions analytic autoethnography in opposition with evocative autoethnography. He defines it in simple terms as a subgenre of analytic ethnography (p. 388-389) involving

... work in which the researcher is (1) a full member in the research group or setting, (2) visible as such a member in the researcher's published texts, and (3) committed to an analytic research agenda focused on improving theoretical understandings of broader social phenomena. (p. 375)

In the same issue of the Journal Ellis and Bochner use their very own evocative autoethnography to critique Anderson's position: "analytical autoethnography runs the risk of co-opting a radical alternative - autoethnography_and using it against itself to reproduce the modernist project of realist ethnography" (Ellis \& Bochner, 2006, p. 434).

\section{Where do I stand in regard to autoethnography?}

I am still trying to find my voice. My storytelling and exhibition of a painting at DOCAM'14 were an attempt to include together 1) the process of personal inquiries as well as the series of events put in motion after interacting with a memorable museum object and 2) the personally meaningful discoveries that ensued. They constitute together an evocative and illustrated narrative. With this paper I attempt to build an evocative autoethnography within a more formal framework. Next, I need to begin the necessary analytical and interpretive work that will validate my use of autoethnography to study the power held by documents to cause epiphanies in those who interact with them. I intend to write in the near future a layered autoethnographic account (Ellis et al., 2011, section 4.1, paragraph 6) of my study as a more traditional research article.

\section{One last thing lest I forget.}

I am indebted to my longtime friend and colleague Kiersten F. Latham who, since the time of our doctoral studies together, has shared her inspirational research on numinous experiences with museum objects (Latham, 2009, 2013), for finding in myself the fortitude to begin this project. I will now tell you a story. 


\section{Listening to Shells and Discovering a Lost World}

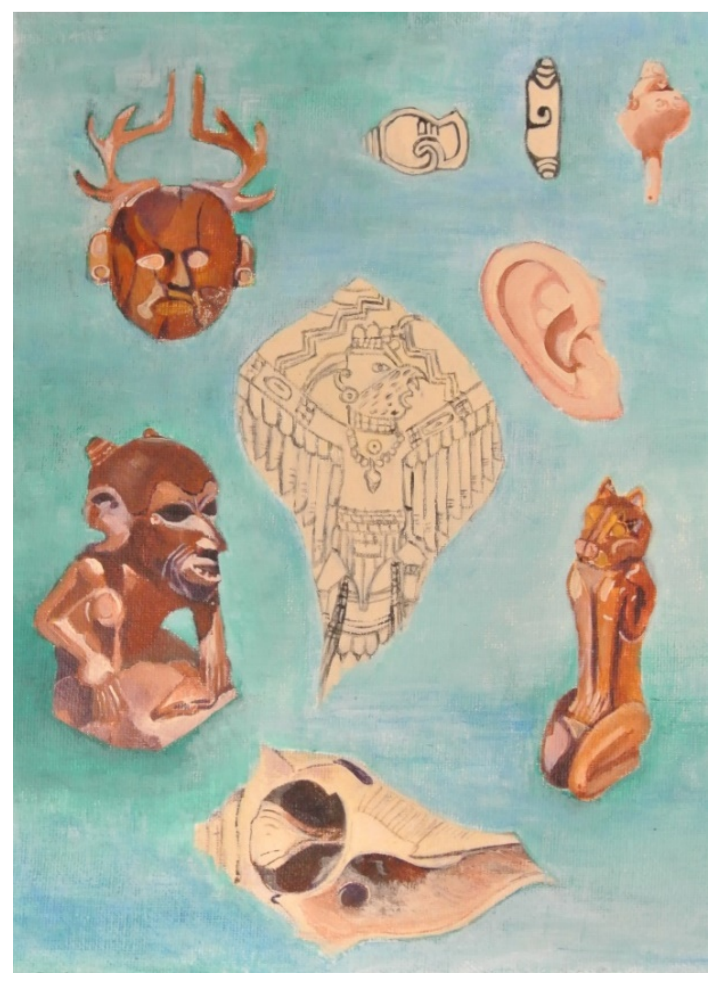

Catherine Closet-Crane (2014). Listening to shells and discovering a lost world. [Painting, acrylic on board-mounted canvas, 9 x12 in.]. Private collection.

Once upon a time Louis and Catherine traveled to Yucatán in search of sea, sun, beaches and Maya ruins for Catherine was studying the history of Pre-Columbian art of the Americas. This is how it all began. It was Louis who noticed it first: a giant white left-handed shell sculpture in the middle of a turnabout in the city of Cancún. Later during that first trip to the Yucatán peninsula, Catherine discovered similar shells on the beach at Celestún on the Gulf coast. These shells were light-colored, the largest ones about two or three inches long; they looked like small conchs and they surprisingly coiled in the opposite direction from all other shells she had ever seen. She collected one regular shell and four shells turning the opposite way to show Louis.

Louis became very excited; he explained that these special shells were lefthanded shells. If you were to put a hand inside a large one, only your left hand would fit. For a very long time it had been a dream of his to find a left-handed shell for they are rare and he is a "left-handed mathematician interested in particle 
physics and particles are chirally symmetrical, which simply means that they have non-superposable mirror images." This has become Louis standard explanation when he recounts the initial discovery of the shells for other people.

Many years later while Catherine was researching information about lefthanded shells, she learned that they are not conchs but are called Lightning Whelks, or more scientifically Busycon perversum as first identified by Linné in 1758 (Wise et al., 2004). She also found out that the whelk is an edible gastropod or snail-like animal in the phylum Mollusca, genus Busycon. In fact the lightning whelk is a predatory mollusk. She also learned that there are several types of right-handed whelks living in different parts of the globe. But there is only one species of left-handed whelk which lives in the Gulf of Mexico and along the Southern Atlantic coast of the United States and the Florida Keyes. In fact, three modern subspecies have been identified in these areas: B. perversum perversum, B. perversum sinistrum, and B. perversum laestomum (Wise et al., 2004) and there even exist fossils of left-handed whelks that are classified Busycon contrarium (Sartori, 2014).

Despite the fact that they have been found at Maya sites in the Yucatán Peninsula, Catherine learned that lightning whelk shells were not used by the Maya people as much as they used the Queen Conch (Strombus gigas; not a lefthanded shell). The Maya used the queen conch so extensively that they had a glyph for it in the Maya script. The conch appears frequently in classic Maya art representations and fashioned into different objects such as trumpets and cups.

Louis and Catherine's next encounter with Busycon perversum was at the Museum of the Red River in Idabel Oklahoma. In a display case of artifacts unearthed at an archeological site in Spiro Oklahoma, it was Louis again who noticed the cups and gorgets made of shell. Taking a closer look, he saw that the most complete incised shell artifact was made of a left-handed shell. Curious, he examined all artifacts and found that all of them were left-handed shell fragments which had probably been used as a drinking cup. Louis got Catherine to leave her examination of stone artifacts housed in horizontal files nearby and directed her attention to the engraved shell cup. "Do you notice anything?" he then said pointing to each artifact in turn "they are all left-handed. Do you think this is a coincidence?" She did not know of course; but she was intrigued. Louis asked one of the museum staff if it was significant that the shell artifacts comprised only left-handed shells. The man did not know either. In fact he was not even sure what a left-handed shell was, but he said that the director might know. The museum was small, and as it is the case often enough in the Midwest, the director/curator was readily available and graciously came to answer questions. They met him and learned that the artifacts where made of lightning whelk shells 
but the director didn't know why and suggested that Catherine and Louis visit the Spiro Mounds complex and ask the archaeologist there. Something happened that captured their imagination. It fueled an urge to understand that would set their minds to work and launch them on a quest for knowledge, a voyage of discovery that combined travels and information seeking activities.

Their visit with the museum director had sparked their curiosity for the Spiro people of whom they had not heard before. In search of the story of this remarkable sea shell artifact, they decided to follow the ancient mollusk's trail back to the site at Spiro. On their next trip to Oklahoma, Louis and Catherine planned a detour to the Spiro Mounds Archeological Center where they joined a group of visitors on a narrated walk through the site. Listening to the archaeologist who interpreted what was left of the pre-Columbian landscape and the Spiro people's constructions was an experience akin to a voyage of exploration through time. They learned that one of the mounds at Spiro, is considered one of the most important North American pre-Columbian sites ever found. Craig Mound had been a burial mound that pot hunters greedily mined in the early $20^{\text {th }}$ century. Artifacts were looted long before anyone could interpret what had been left undisturbed for hundreds of years; they were sold to antiquities dealers and collectors and dispersed in private collections and museums. Learning from the archeologist that Craig Mound had been dynamited by the men of the "Pocola Mining Company" (The University of Texas at Austin, 2003) and imagining broken artifacts and shreds of textiles littering the ground where the mound once stood triggered apocalyptic visions of carnage in Catherine's mind. Louis was angry: "always the same story!" he exclaimed "Greed, greed, greed." It broke their hearts and angered them, but it also fueled a common desire to learn all they could about the Spiro people and their culture. They began to ask questions to the archeologist. Louis asked about the provenance of the incised shell seen at the museum and whether it was meaningful that it was a left-handed lightning whelk. The archeologist answered that the people who built the village and regional leadership center at Spiro were a Caddoan-speaking group that traded from the Gulf of Mexico to the Great Lakes and from the coast of Florida to the Rockies. Because of their peculiar left-handedness and therefore their rarity, the Spiro people had secured a monopoly on the trade of lightning whelks, which they obtained from Florida's Southern Gulf coast. Archeologists think that such objects made of the shells from the lightning whelk served to identify the official emissaries and ambassadors from Spiro; being in their possession also authenticated the messages envoys dispatched to far away local leaders about religious or political matters. Catherine realized then that the engraved lightning whelks had functioned as a kind of pre-Columbian government documentation or "passport." The shell from the Museum of the Red River was more than a document in the museum; it had always been a document! She excitedly shared 
that epiphany with Louis who exclaimed: "you need to write about that!" And so it was that the archeologist's answers set in motion the writing of this story.

A question was now forming in their minds, where did the shells come from? Of course they had found those in Yucatán, but in a trip to the Florida Keyes Catherine had also found minuscule left-handed shells on a small beach into the mangroves of the Florida Bay near Key Largo. She wondered . . . could the Spiro shells have come from the Southern tip of Florida, somewhere near the Everglades? During another vacation in Florida they decided to explore the Gulf coast of the Everglades, South of Naples. There they not only found shells but live specimens of Busycon perversum. However, a more important discovery was their encounter with the reproduction of Calusa Indian artifacts in the small Historical Museum on Marco Island.

At the museum, an exquisite wood carving was on display that represented an anthropomorphic cat. It was the replica of an artifact found during the excavation of a site at Key Marco by the Smithsonian Institution in 1896. At the end of the 19th century, knowledge of preservation techniques was not very developed and painted objects retrieved from the waterlogged site lost their colors. Fortunately, Wells Sawyer, an artist and photographer (Fowler Williams, 1991, p. 56) who was present at the excavation site painted watercolors capturing the colors of the painted objects; the Historical Museum displayed reproductions of Sawyer's paintings. The water colors had been used to create reproductions of the painted objects, including one of an amazingly beautiful carving of the head of a Florida deer.

Catherine and Louis found out that these artifacts had belonged to Calusa Indians who were also mound builders; they built their mounds out of shells. The couple wondered "could the Calusa people have been providing the lightning whelks to the Caddoan people of Spiro? What had become of them?" They learned that at the time of contact with the Spanish, the parties of Ponce de Léon and Hernando de Cordóba had been attacked by tall Calusa warriors traveling in canoes. It happened repeatedly between 1513 and 1521 resulting in Ponce de Léon ultimately getting killed. As sailors who went as far as Cuba and as fierce warriors the Calusa had built an Empire and controlled most of South Florida; but the Calusa tribe lost control of it and died out in the $18^{\text {th }}$ century decimated in raids by enemy Indian tribes allied with the Europeans, and epidemics of diseases that came with the Spanish and French explorers. It is said that Calusa survivors of the diseases and tribal wars went to Cuba when Florida became British in 1763 and that a few may have been absorbed in the Seminole tribe. There was little more information about the Calusa at the Marco Island Historic museum and Catherine and Louis had to go back home to Kansas; but they were excited. 
Catherine began internet searches for more information about the Calusa. She learned that there were Calusa shell mounds along the Southwestern Florida gulf coast from the Everglades to Estero bay near Fort Meyers. The more she learned, the more delighted she was and she began to imagine connections between Spiro and the Calusa people. She found out that at time of contact with the Spanish the Calusa culture presented Mississippian social patterns and the Calusa society was stratified like the Caddoan society. The Calusa also built shell mounds complexes that included temple mounds and burial mounds like Mississippian people but the Calusa also engineered unique and sophisticated systems of canals to travel by canoe. Could they have collected and sold the lightning whelks to the Spiro people?

Catherine and Louis could not resist planning another trip to Florida to explore the coast between Marco Island and Fort Meyers in search of Calusa historical sites. Once there, they visited Lovers' Key State Park near Estero Bay where they walked the trails of Black Island. It was a strange feeling, walking on ancient shells that were mostly visible on the trails. Everywhere else the luxuriant vegetation had taken over and the shells disappeared under a layer of organic soil. Spotting wildlife, the couple thought about the way the Calusa captured with their carvings the beauty of ducks and deer that they must also have hunted. They imagined Calusa fisherfolk throwing their nets in the waters of Estero Bay. Following the convoluted trails snaking through the forest and between waterways (could they have been canals?) they glimpsed views of the distant island of Mound Key and expected to hear the rhythmic paddling noise of ancient dugout canoes. Mound Key is an archeological State Park accessible by boat only; it was a major ceremonial center of the Calusa until 1566 when the Spanish established a short lived settlement and fort on the island (Mound Key Archeological State Park, n.d.). After their hike Catherine and Louis walked to the nearby beach, a truly amazing beach of pure white sand. They could not help but feel a bittersweet sadness for the lost world of the Calusa, a people who, they imagined, the Spiro people may have connected with by land. They began dreaming, and what if the Calusa had also connected by sea the Mississipian Eastern Woodland Culture and the Maya Culture of Yucatán? . . . But that is another adventure looking for connections into what Louis likes to call "the black holes of history."

For now the story ends when Catherine and Louis recently reunited in Kent with Mark, an archeologist who has studied both the Calusa and the Spiro people. They asked Mark if it was possible that the Calusa had been the sole providers of lightning whelks to the Spiro people, who in turn, had a trade monopoly with the Calusa. Mark's eyes were gleaming and, with a grin worthy of the Cheshire cat, he answered: "yes ... probably." 


\section{Epilogue}

Louis and Catherine feel good to have elucidated for themselves the mystery of Spiro's engraved shell by following an unchartered trail through museums, online searches, state parks, scholarly articles, and historic sites. Best of all was that a series of epiphanies took them on a journey replete with transformative experiences that changed their understanding of the long lost world in which the Spiro and Calusa people once lived, and of American history. 


\section{References}

Alvesson, M. (2003). Methodology for close up studies - struggling with closeness and closure. Higher Education, 46, 167-193.

Anderson, L. (2006). Analytic autoethnography. Journal of Contemporary Ethnography, 35(4), 373-395.

Bouchet, P. \& Fraussen, K. (2014). Busycon perversum (Linnaeus, 1758), in World Register of Marine Species [Online document]. Retrieved from http://www.marinespecies.org/aphia.php?p=taxdetails\&id=217074.

Briet, S. (1951). Qu'est-ce que la documentation? [What is documentation?]. Paris: Éditions Documentaires Industrielles et Techniques. (Digital reproduction of the original edition). Retrieved from http://martinetl.free.fr/suzannebriet/questcequeladocumentation/briet.pdf.

--. (2006). What is documentation? (R. Day, L. Martinet, \& H. G.B. Anghelescu, Trans. pp. 9-33). Retrieved from http://ella.slis.indiana.edu/ roday/what\%20is\%20documentation.pdf.

--. (2008). Qu'est-ce que la documentation? (Martinet, L. Revised and made available online). Retrieved from http://martinetl.free.fr/suzannebriet/questcequeladocumentation/. (Original work published 1951).

Buckland, M. (1991). Information as thing. Journal of the American Society for Information Science, 42, 351-360.

Buckland, M. (1998). What is a "document"? In T. B. Hahn \& M. Buckland (Eds.), Historical Studies in Information Science (pp. 215-220). Medford, NJ: Information Today.

Carr, D. (2004). The Promise of Cultural Institutions. Lanham, MD: AltaMira Press.

--. (2006). A Place Not a Place: Reflection and Possibility in Museums and Libraries. Lanham, MD: Rowman \& Littlefield.

Chang, H. (2008). Autoethnography as Method. Walnut Creek, CA: Left Coast Press. 
--. (2013). Individual and collective autoethnography as method; a social scientist's perspective. In S. Holman Jones, T. E. Adams, \& C. Ellis (Eds.), Handbook of Autoethnography, (pp. 107-122). Walnut Creek, CA: Left Coast Press.

Closet-Crane, C. (2009). (Re)creating the academic library as place for the 21st century? A critical analysis of discourse in discussions of academic library planning and design (Doctoral Dissertation). Retrieved from ProQuest Dissertation and Theses. (Publication Number: 3399158). http://pqdtopen.proquest.com/pubnum/3399158.html

Ellis, C. (1993). "There are survivors": telling the story of sudden death. The Sociological Quarterly, 34 (4), 711-730.

--. (1997). Evocative autoethnography: Writing emotionally about our lives. In W. G. Tierney and Y. S. Lincoln (Eds.), Representation and the text: Reframing the narrative voice (115-142). Albany: State University of New York Press.

--. (1999). Heartful autoethnography. Journal of Qualitative Health Research, 9(5), 669-683.

--. (2004). The ethnographic I: A methodological novel about autoethnography. Walnut Creek, CA: AltaMira Press.

Ellis, C., Adams, T. E. \& Bochner, A. P. (2011). Autoethnography: An Overview. Forum Qualitative Sozialforschung / Forum: Qualitative Social Research, 12(1), Art. 10. Retrieved from http://nbnresolving.de/urn:nbn:de:0114-fqs1101108.

Ellis, C. \& Bochner, A. ( 2000). Autoethnography, personal narrative, reflexivity: Researcher as subject. In N. K. Denzin and Y. S. Lincoln (Eds.), Handbook of qualitative research, 2nd ed. (733-768). Thousand Oaks, CA: Sage.

-- \& --. ( 2006). Analyzing analytic autoethnography: an autopsy. Journal of Contemporary Ethnography, 35(4), 429-447.

Ericksson, T. (2010). Being native - distance, closeness and doing auto/selfethnography. ArtMonitor, 8, 91-100. Retrieved from https://gupea.ub.gu.se/handle/2077/24689.

Fowler Williams, L. (1991). The Calusa Indians maritime peoples of Florida in the age of Columbus. Expedition, 33(2), 55-61. 
Gergen, M. M. \& Gergen, K. J. (2010). Performative Social Science and Psychology. [13 paragraphs]. Forum Qualitative Sozialforschung / Forum: Qualitative Social Research, 12(1), Art. 11. Retrieved from http://nbn-resolving.de/urn:nbn:de:0114-fqs1101119.

Hamdan, A. (2012). Autoethnography as a genre of qualitative research: A journey inside out. International Journal of Qualitative Methods, 11 (5), 585-606. Retrieved from http://ejournals.library.ualberta.ca/index.php/IJQM/article/view/5130/14578.

Hemmingson, M. (2008). Zona Norte: The Post-Structural Body of Erotic Dancers and Sex Workers in Tijuana, San Diego and Los Angeles: An Auto/ethnography of Desire and Addiction. Newcastle Upon Tyne, UK: Cambridge Scholars Publishing.

Latham, K. F. (2009). Numinous Experiences with Museum Objects. Dissertation, School of Library \& Information Management, Emporia State University.

Latham, K. F. (2012). Museum object as document: Using Buckland's information concepts to understand museum experiences. Journal of Documentation, 68(1), 45-71.

Mound Key Archeological State Park. (n.d.). Retrieved from http://www.floridastateparks.org/moundkey/.

Muncey, T. (2010). Creating Autoethnographies. Thousand Oaks, CA: Sage.

Sartori, A. (2014). Busycon Contrarium (Conrad, 1840). [Online document]. World Register of Marine Species. Retrieved from http://www.marinespecies.org/aphia.php?p=taxdetails\&id=747340.

Schutz, A. \& Luckmann, T. (1973). The Structures of the Life-World. (R. M. Zaner \& H. T. Engelhart, Trans.). Evanston, IL: Northwestern University Press.

The University of Texas at Austin. (2003, August 6). "Spiro and the Arkansas Basin." Retrieved from http://www.texasbeyondhistory.net/tejas/fundamentals/spiro.html.

Wise, J. Harasewich, M. G., \& Dillon, R. T. (2004). Population divergence in the sinistral whelks of North America, with special reference to the east 
Florida ecotone. Marine Biology, 145, 1167-1179. DOI 10.1007/s00227004-1411-x.

Woodbrook, R. N. (2012). Deeply Connective Encounters with Museum Objects. Thesis, Museology Graduate Program, University of Washington.

Retrieved from http://hdl.handle.net/1773/20603. 